\title{
Damage-Associated Molecular Pattern Molecule
}

National Cancer Institute

\section{Source}

National Cancer Institute. Damage-Associated Molecular Pattern Molecule. NCI Thesaurus. Code C118474.

Molecules released during times of cellular stress or necrosis, that can induce or perpetuate the non-infectious immune response. 